Reprod. Nutr. Dévelop., 1984, 24 (3), 281-296.

\title{
Relationships between Leydig cell morphometry and plasma testosterone during postnatal development of the monkey, Macaca fascicularis
}

\author{
J.-P. FOUQUET, Nicole MEUSY-DESSOLLE, D. C. DANG $\left(^{*}\right)$
}

Laboratoire de Physiologie de la Reproduction des Vertébrés, Université Paris VI, 75230 Paris Cedex 05 and I.N.R.A., 78350 Jouy-en-Josas, France.

(*) Laboratoire d'Anatomie, UER Biomédicale, 45, rue des Saints-Pères, 75006 Paris.

Summary. In neonates $(0$ to $3-4$ months), the testis contained a mean number of $4.6 \times 10^{6}$ Leydig cells representing $4.2 \%$ of its volume; Leydig cell cytoplasm contained $10.2 \%$ of SER. In infants (up to 45 months), Leydig cells regressed but their number increased ; their volume density did not change. Leydig cell cytoplasmic volume $\left(454 \mu \mathrm{m}^{3}\right)$, which was about 2.5 -fold less than in neonates $\left(1119 \mu \mathrm{m}^{3}\right)$ or adults $\left(1170 \mu \mathrm{m}^{3}\right)$, contained only $8.7 \%$ of SER. During meiosis stage (38-52 months), Leydig cell number and volume density did not vary but the cells reached a maximal size and an amount of SER comparable with that at birth was measured. When spermatogenesis was complete, the Leydig cells represented no more than $0.8 \%$ of testis volume, but their number and SER content were significantly increased. Except for a significant decrease when spermatogenesis was completed, Leydig cell lipid content did not change during development, and the volume density of mitochondria did not vary.

The mean level of plasma testosterone was $2 \mathrm{ng} / \mathrm{ml}$ in neonates and $0.4 \mathrm{ng} / \mathrm{ml}$ in infants ; it increased to $3 \mathrm{ng} / \mathrm{ml}$ during onset of meiosis and reached $10 \mathrm{ng} / \mathrm{ml}$ in adults. The profile of testosterone was positively and significantly correlated with the total volume and total number of Leydig cells ( $P<0.01$ and $P<0.02$, respectively) and with changes in their cytoplasmic volume $(\mathrm{P}<0.001)$. Moreover, plasma testosterone levels were positively and significantly correlated with changes in Leydig cell SER content i.e. SER volume density and mean absolute volume per cell $(P<0.001)$, total SER in the whole testis $(P<0.01)$.

\section{Introduction.}

Leydig cells are the main source of testicular testosterone. Their ultrastructure has been described in detail in the adult mammal (Christensen, 1975) and analysed stereologically in rat (Mori and Christensen, 1980), guinea-pig (Mori et al., 1980), mouse (Mori et al., 1982a) and man (Mori et al., 1982b). Leydig cells differentiate in the fetus, then regress from the end of fetal life or 
after birth. The extent of regression varies with the species, their definitive development occurring at puberty (Christensen, 1975). The biphasic development of Leydig cells coincides with changes in plasma testosterone levels which are high in the fetus (Faiman et al., 1981), very low during infancy, and significantly increased at puberty (Levasseur and Thibault, 1980 ; Swerdloff and Heber, 1981). Postnatal variations in Leydig cell number and/or size are parallel to the timing of testosterone secretion in rabbit (Gondos et al., 1976, 1977) and boar (MeusyDessolle, 1975 ; Van Straaten and Wensing, 1978 ; Peyrat et al., 1981 ; Allrich et al., 1983). Ultrastructural changes in the Leydig cells of rat (Lording and de Kretser, 1972), rabbit (Gondos et al., 1976) and the monkey, Cercopithecus aethiops (Camatini and Franchi, 1981 ; Camatini et al., 1981), suggest that the ability to synthesize testosterone may vary during postnatal development, but distinct correlations between these two processes were not demonstrated. Only morphometric analysis has been able to show that the ability of the testis to synthesize testosterone is correlated with the amount of smooth endoplasmic reticulum (SER) of the Leydig cells (Zirkin et ąl., 1980 ; Ewing et al., 1983).

In the present work, Leydig cell development was studied by light and electron microscopy from birth to puberty in the crab-eating monkey, Macaca fascicularis. The functional differentiation of the Leydig cells was estimated by morphometric analysis of the organelles related to steroidogenesis, i.e. SER, mitochondria and lipid droplets. Plasma testosterone levels were also measured in the same animals. A study of the fetal period has been presented elsewhere (Fouquet et al., 1983).

\section{Material and methods.}

1. Animals. - Monkeys (Macaca fascicularis) were raised in captivity according to Dang (1977): Ninety-nine animals were used for plasma testosterone measurement from birth to sexual maturity; except for 2 adults, their age was known. Thirty-nine were used for microscopic studies of the testis, as follows : 24 of various ages were castrated and 15 (36-54 months) were surveyed, before castration, by biopsy every 3 months alternatively on the right and left testis for 6 to 12 months (longitudinal study) in order to obtain information on the critical period of the establishment of spermatogenesis.

2. Surgical techniques and tissue preparation. - As in previous reports (Fouquet, 1982 ; Fouquet et al., 1983), biopsies and smaller testes (before onset of meiosis) were cut and fixed by immersion; the other testes were fixed by perfusion according to the following method: the blood of one testicle of a totally anesthetized animal was washed out by perfusion of a sterile complex isotonic saline solution $\left(B_{27}\right)$ to which heparin $(40 \mathrm{lU} / \mathrm{ml})$ and aminocain $(2.4 \mathrm{mg} / \mathrm{ml})$ were added. Using a silastic catheter, one of the lateral testicular arteries was perfused until the effluent pampiniform veins showed a limpid flow. The spermatic cord was then clamped and cut, allowing the blanched testicie to be taken from the sterile operative field. The gland was further fixed by injecting 
a fixative mixture (glutaraldehyde-paraformaldehyde) into the catheter, as previously described (Fouquet, 1982).

Blocks of about $2 \times 2 \times 1 \mathrm{~mm}$ were postfixed with $\mathrm{OsO}_{4}$ and embedded in Epon. Toluidine blue-stained $1-\mu \mathrm{m}$ thick sections were observed with a light microscope and uranyl acetate lead citrate-stained thin sections (pale gold interference color) were observed with an electron microscope (Philips 201 and JEOL $100 \mathrm{~B}$ ).

3. Morphometric analysis. - The procedures have been described in detail elsewhere (Fouquet et al., 1983). Briefly, the volume densities of Leydig cells and organelles were determined by the point-counting method of Weibel et al. (1966) using a double lattice grid which allowed 350 and 1150 test points to be counted on light and electron micrographs, respectively.

Light microscopy. - Toluidine blue-stained sections were used for determination of Leydig cell volume density $\left(V_{v}\right.$ cells). From birth to onset of meiosis, 24 micrographs/animal ( 2 blocks $\times 2$ sections $\times 6$ areas ; magnification $: \times 630$ ) were selected at random and analysed. At later stages, 36 micrographs/animal (3 blocks $\times 2$ sections $\times 6$ areas) were analysed.

Electron microscopy. - Thin sections of the corresponding blocks were observed at two different magnifications. Low magnification views $(\times 2500)$ of 20-25 Leydig cells/animal were used to determine mean whole-cell volume ( $V$ cell) and cytoplasmic volume ( $\mathrm{V}$ cyt). $\mathrm{V}$ cyt $=\mathrm{V}$ cell $-\mathrm{V}$ nucleus, $\mathrm{V}$ nucleus being calculated from the formula of an ellipsoid $\left(\pi w^{2} L / 6\right)$, where $w$ and $L$ were the width and length, respectively, of the ovoid nucleus. Substituting testis volume ( $V$ testis) for testis weight, the total volume of the Leydig cells was: $V_{\text {testis }} \times V_{v}$ cells; their total number was: $V_{\text {testis }} \times V_{v}$ cells $/ V$ cell. High magnification views (X 25000 ) of 20-25 Leydig cells/animal were taken at random to determine the volume densities of organelles $\left(V_{v}\right.$ SER, $V_{v}$ mitochondria, $V_{v}$ lipids) as the percentage of cytoplasmic volume. The absolute volume of an organelle per Leydig cell was : $V_{v}$ organelle $\times V$ cyt.

With the magnification used $(X 25000)$ SER was identified unambiguously (see fig. 19). For all volume density determinations, the number of measurements/animal, grouping data up to SEM/X was less than $10 \%$, was sufficient to ensure sampling adequacy (Bolender, 1978).

4. Measurement of testosterone. - Blood samples were collected from the radial or saphena vein during the afternoon once or twice a month at all ages up to castration. Plasma testosterone levels were determined by a RIA method using ether for extraction and an isooctane-ethyl acetate mixture $(80 / 20, \mathrm{~V} / \mathrm{V})$ for chromatography on celite column (chromatolithe A, Biomérieux Laboratories), according to a technique described elsewhere. This technique allowed the separation of four androgens and $17 \beta$-estradiol by gradual elution with isooctaneethyl acetate mixtures of increasing polarity.

The antibody was raised in rabbit against 3-O-carboxy-methyloximetestosterone coupled with bovine serum albumin (BSA) and saturated with BSA before use. Antibody specificity showed the following main cross reactions: 
$28.4 \%$ with $5 \alpha$-dihydrotestosterone, $10.8 \%$ with $3 \beta-5 \alpha$-androstanediol and $0.9 \%$ with $\Delta 4$-androstenedione (Dang and Meusy-Dessolle, 1979). Assay sensitivity was about $5 \mathrm{pg}$ per tube.

Intra-assay variabilities were 12.4 and $6.5 \%$ for 0.62 and $7.6 \mathrm{ng} / \mathrm{ml}$ of plasma, respectively. The interassay coefficients of variation were $9.9 \%$ for $0.42 \mathrm{ng} / \mathrm{ml}$ of plasma, $7.7 \%$ for $1.59 \mathrm{ng} / \mathrm{ml}$ of plasma and $6.3 \%$ for $6.13 \mathrm{ng} / \mathrm{ml}$ of plasma. Mean water blank was $14 \mathrm{pg}$. Mean recovery after extraction plus chromatography was $72.8 \pm 1.3 \%$.

5. Statistical analysis. - The data obtained throughout postnatal development were grouped into five developmental periods (see below) and the results shown as means \pm SEM. One-way analysis of variance was used to determine significant quantitative differences between stages. The Duncan new multiple range test was used for specific comparisons. Regression analysis was used for correlation studies.

\section{Results.}

Leydig cell development and changes in plasma testosterone levels were analysed and compared in relation with animal age and progression of the germ cell line. Five developmental periods were considered : neonatal (0 to 3-4 months) with A spermatogonia, infancy (from 3-4 months up to onset of meiosis) with A spermatogonia, meiosis with the appearance of primary spermatocytes, spermiogenesis with round up to maturing spermatids, complete spermatogenesis with spermiation.

\section{Body weight and testis weight profiles (table 1).}

Body weight increase was practically linear from birth to puberty. Testis growth was equally linear in neonates and infants but from onset of meiosis, it exceeded that of body weight as shown by the significant $(P<0.001)$ increase of

TABLE 1

Body and testis weights at different developmental periods.

\begin{tabular}{cccccc}
\hline $\begin{array}{c}\text { Developmental } \\
\text { period } \\
\text { (age in months) }\end{array}$ & $\begin{array}{c}\text { Neonatal } \\
0-3 \\
(\mathrm{n}=4)\end{array}$ & $\begin{array}{c}\text { Infancy } \\
12-45 \\
(\mathrm{n}=5)\end{array}$ & $\begin{array}{c}\text { Meiosis } \\
42-52 \\
(\mathrm{n}=3)\end{array}$ & $\begin{array}{c}\text { Spermiogenesis } \\
34-46 \\
(\mathrm{n}=5)\end{array}$ & $\begin{array}{c}\text { Complete } \\
\text { spermatogenesis } \\
44-53 \\
(\mathrm{n}=3)\end{array}$ \\
\hline $\begin{array}{c}\text { Body } \\
\text { weight }(\mathrm{g})\end{array}$ & $747.5 \pm 77$ & $2598 \pm 307$ & $3283 \pm 457$ & $3828 \pm 263$ & $5692 \pm 190$ \\
\hline $\begin{array}{c}\text { Testis } \\
\text { weight }(\mathrm{mg})\end{array}$ & $139 \pm 18$ & $510 \pm 48$ & $1401 \pm 255$ & $3290 \pm 663$ & $18867 \pm 262$ \\
\hline $\begin{array}{l}2 \text { testes } \\
\text { b. weight }\end{array}$ & $0.037 \pm 0.001$ & $0.040 \pm 0.001$ & $0.084 \pm 0.004$ & $0.175 \pm 0.041$ & $0.665 \pm 0.029$ \\
\hline
\end{tabular}


the 2 testes/body weight ratio. These observations are in agreement with those reported by Steiner and Bremner (1981).

\section{Development of the Leydig cell population (table 2).}

The volume density of Leydig cells remained stable from birth to spermiogenesis, but was significantly lower $(P<0.01)$ when spermatogenesis was complete. This decrease appeared to be closely related to the size increase of seminiferous tubules (canalization) occurring at the end of development. However, the total volume occupied by Leydig cells increased linearly throughout development. The mean number of Leydig cells per testis increased significantly in infants compared to neonates $(P<0.001)$; it remained almost constant during meiosis and spermiogenesis $(P<0.05)$ but was more elevated in adults $(P<0.05)$. The number of Leydig cells per $\mathrm{cm}^{3}$ of testis increased from birth to infant stage $(P<0.05)$ but was lower $(P<0.05)$ during meiosis stage; the subsequent decrease was not significant $(P>0.05)$.

TABLE 2

Development of Leydig cell population.

\begin{tabular}{|c|c|c|c|c|c|}
\hline $\begin{array}{l}\text { Developmental } \\
\text { period } \\
\text { (age in months) }\end{array}$ & $\begin{array}{c}\text { Neonatal } \\
0-3\end{array}$ & $\begin{array}{c}\text { Infancy } \\
7-45\end{array}$ & $\begin{array}{c}\text { Meiosis } \\
38-52\end{array}$ & $\begin{array}{l}\text { Spermiogenesis } \\
34-54\end{array}$ & $\begin{array}{c}\text { Complete } \\
\text { spermatogenesis } \\
\text { from } 44\end{array}$ \\
\hline $\begin{array}{l}\text { Leydig cell } \\
\text { vol. density } \\
\% \text { testis volume }\end{array}$ & $\begin{array}{c}4.2 \pm 0.3 \\
(n=5)\end{array}$ & $\begin{array}{r}3.2 \pm 0.4 \\
(\mathrm{n}=11)\end{array}$ & $\begin{array}{c}3.3 \pm 0.7 \\
(n=5)\end{array}$ & $\begin{array}{c}2.7 \pm 0.5 \\
(n=7)\end{array}$ & $\begin{array}{c}0.8 \pm 0.1 \\
(n=4)\end{array}$ \\
\hline $\begin{array}{l}\text { Leydig cell } \\
\qquad\left(\mathrm{mm}^{3}\right) / \text { testis }\end{array}$ & $5.9 \pm 0.8$ & $19.1 \pm 4.7$ & $44 \pm 7.8$ & $80.8 \pm 19.6$ & $158.2 \pm 21.7$ \\
\hline \multirow[t]{2}{*}{$\begin{array}{l}\text { Number } \\
\left(\times 10^{6}\right\rangle\end{array}$} & $4.6 \pm 0.7$ & $34 \pm 8.6$ & $36 \pm 6.1$ & $59 \pm 13$ & $119 \pm 18$ \\
\hline & $\begin{array}{l}33 \pm 2 \\
(n=4)\end{array}$ & $\begin{array}{c}63.8 \pm 9.4 \\
(n=5)\end{array}$ & $\begin{array}{r}28.9 \pm 9 \\
(n=3)\end{array}$ & $\begin{array}{c}20.6 \pm 5.2 \\
(n=5)\end{array}$ & $\begin{array}{l}6.3 \pm 0.9 \\
(n=3)\end{array}$ \\
\hline
\end{tabular}

\section{Leydig cell morphometry (table 3).}

Neonatal period. - During the first 3 to 4 months after birth, the Leydig cells were large, polygonal in shape and often grouped into islets (figs. 1, 2), the cellular and cytoplasmic volumes being the same $(P>0.05)$ as during adulthood. They contained a tubulo-vesicular SER forming membranous whorls around some lipid droplets or at the cell periphery (figs. 4, 5). Mitochondria of varying size and shape, with tubular and lamellar cristae, were mainly associated with the SER (fig. 3). The Leydig cells also contained a large number of lipid droplets and their rough endoplasmic reticulum (RER) was reduced to solitary cisternae but the 
dictyosomes were well developed (figs. 4, 5). At this stage, the mean plasma testosterone level was $2.14 \mathrm{ng} / \mathrm{ml}$ with large individual variations.

TABLE 3

Morphometry of Leydig cells and plasma testosterone level.

\begin{tabular}{|c|c|c|c|c|c|c|}
\hline \multicolumn{2}{|c|}{$\begin{array}{l}\text { Developmental } \\
\text { period } \\
\text { (age in months) }\end{array}$} & $\begin{array}{l}\text { Neonatal } \\
0-3 \text { to } 4 \\
(n=5)\end{array}$ & $\begin{array}{c}\text { Infancy } \\
7-45 \\
(n=11)\end{array}$ & $\begin{array}{c}\text { Meiosis } \\
38-52 \\
(n=5)\end{array}$ & $\begin{array}{c}\text { Spermiogenesis } \\
\begin{array}{c}34-54 \\
(n=7)\end{array}\end{array}$ & $\begin{array}{c}\text { Complete } \\
\text { spermatogenesis } \\
\text { from } 44 \\
(n=4)\end{array}$ \\
\hline \multirow{2}{*}{$\begin{array}{l}\text { Leydig cell } \\
\text { Vol. }\left(\mu \mathrm{m}^{3}\right)\end{array}$} & whole cell & $1275 \pm 29$ & $521 \pm 50$ & $1180 \pm 59$ & $1329 \pm 27$ & $1333 \pm 39$ \\
\hline & cytopl. & $1119 \pm 28$ & $454 \pm 48$ & $1017 \pm 56$ & $1166 \pm 25$ & $1170 \pm 35$ \\
\hline \multirow{3}{*}{$\begin{array}{l}\text { Vol. } \\
\text { density }\end{array}$} & mitoch. & $17.3 \pm 0.6$ & $16.9+0.6$ & $17.0 \pm 1.2$ & $17.4+0.8$ & $18.2+0.8$ \\
\hline & lipid & $12.0 \pm 1.6$ & $11.2 \pm 1.7$ & $17.7 \pm 2.7$ & $15.0 \pm 1.6$ & $4.9 \pm 1.2$ \\
\hline & SER & $10.2 \pm 0: 4$ & $8.7 \pm 0.3$ & $11.7 \pm 0.8$ & $13.4 \pm 0.6$ & $14.1 \pm 0.4$ \\
\hline \multirow{3}{*}{$\begin{array}{l}\text { Vol. }\left(\mu \mathrm{m}^{3}\right) \\
\text { per cell }\end{array}$} & mitoch. & $194.2 \pm 9.3$ & $76.4 \pm 8.6$ & $170.2+7.1$ & $202.2+7.9$ & $213.4+14.4$ \\
\hline & lipid & $135.5 \pm 20.8$ & $58.4 \pm 12.9$ & $177.1 \pm 22.9$ & $175.3 \pm 18.4$ & $56.5 \pm 13$ \\
\hline & SER & $115 \pm 7.6$ & $39.7 \pm 4.5$ & $119.3 \pm 11.2$ & $156.4 \pm 8.7$ & $164.8 \pm 3.2$ \\
\hline \multirow{2}{*}{$\begin{array}{l}\text { Testosterone } \\
\text { (ng/ml) }\end{array}$} & * & $2.02 \pm 0.48$ & $0.43 \pm 0.05$ & $2.98 \pm 1.31$ & $3.92 \pm 0.59$ & $10.3 \pm 2.27$ \\
\hline & $* *$ & $\begin{array}{c}2.14 \pm 0.53 \\
(n=14)\end{array}$ & $\begin{array}{c}0.43 \pm 0.03 \\
(n=45)\end{array}$ & $\begin{array}{c}3.42 \pm 0.86 \\
(n=12)\end{array}$ & $\begin{array}{c}3.93 \pm 0.63 \\
(n=9)\end{array}$ & $\begin{array}{l}7.17 \pm 1.8 \\
\langle n=159\rangle\end{array}$ \\
\hline
\end{tabular}

Results are means \pm SEM.

Organelle volume density is expressed as a percentage of Leydig cell cytoplasmic volume.

* Plasma testosterone levels are those of the animals studied morphometrically.

* Mean testosterone levels of a greater number of animals.

Infancy. - After the end of the neonatal period (up to 45 months), Leydig cell volume was significantly lower $(P<0.001)$ than during that period, but showed large individual variations. In some cases, the Leydig cells appeared isolated and were fibroblast-like (figs. 6, 8), their cytoplasmic volume being fivefold less than that of adult cells. In other cases, they remained grouped into

\section{PLATE I}

Leydig cells (L) in the neonate.

FIGS. 1, 2. - Light microscope views at 9 days and at 3 months.

Some $\mathrm{Ad}$ and $\mathrm{Ap}$ spermatogonia are visible. $\times 630$.

FIGS. 3, 4, 5. - Ultrastructural aspects of Leydig cells : prominent SER and dictyosomes (d), scattered mitochondra with tubular cristae.

From birth (fig. 3) to maturity (see fig. 18) the Leydig cells also contained some unusual, possibly degenerating, mitochondria $(\rightarrow)$ with a dense matrix almost devoid of cristae (Ci). Fig. $3: 9$ days, $\times 25000$; fig. $4: 9$ days, $\times 12500$; fig. $5: 2$ months, $\times 13500$. 
islets (figs. 7, 9), their cytoplasmic volume being only twofold less than that of adult cells. However, a longitudinal study using biopsy (figs. 8, 9, for example) on a group of 5 animals showed that the cytoplasmic volume of infant Leydig cells compared to that of adult cells was $23.8 \pm 2 \%$ and $64.6 \pm 4 \% 6$ to 9,3 to 4 months, respectively, before onset of meiosis (significant difference : $P<0.001)$.

Whatever the reduction in Leydig cell size, the SER was mostly represented by scattered tubules or short cisternae (very rare membranous whorls, figs. 10, 11), and its volume density was significantly reduced $(P<0.05)$ compared to that observed during the neonatal period. On the other hand, the mitochondria did not show obvious differences and their volume density as well as that of the lipid was not significantly different $(P>0.05)$.

Mean plasma testosterone level during infancy was $0.43 \pm 0.05 \mathrm{ng} / \mathrm{ml}$ and thus significantly lower $(P<0.001)$ than during the neonatal period. In the group of 5 animals monitored by biopsy, 4 showed a significant rise $(P<0.001)$ of testosterone 1 to 3 months before onset of meiosis : $4.35 \pm 1.04 \mathrm{ng} / \mathrm{ml}$ (data not included in table 3).

Meiosis. - Leydig cells (figs. 12, 13) showed a significant increase ( $P<0.001)$ in whole-cell and cytoplasmic volume compared to infancy. Their SER was better differentiated with packed areas of tubules and cisternae and membranous whorls around lipid droplets (fig. 14); volume density was significantly increased $(P<0.001)$. Elongated mitochondria with longitudinal cristae were often seen (fig. 15), but the volume density of these organelles as well as that of lipids did not show significant changes $(P>0.05)$.

The mean plasma testosterone level $(3.42 \pm 0.86 \mathrm{ng} / \mathrm{ml})^{\bullet}$ in 12 animals was significantly more elevated $(P<0.001)$ than during infancy. However, this increase was noted in 9 animals $(4.43 \pm 0.92 \mathrm{ng} / \mathrm{ml})$; in three others the plasma testosterone level fell to within the infant range $(0.48 \pm 0.09 \mathrm{ng} / \mathrm{ml})$.

Spermiogenesis and complete spermatogenesis. - During spermatid differentiation (fig. 16), Leydig cell volume, organelle volume density and testosterone level did not change significantly $(P>0.05)$. When spermatogenesis was completed (figs. 17, 18, 19), volume density of SER was significantly

PLATE ॥

Regressed Leydig cells (L) in the infant.

FIGS. 6-9. - Light microscope views. $\times 630$.

Fig. $6: 14$ months; fig. $7: 28$ months; figs. 8,9 (biopsies of the same monkey) : fibroblast-like Leydig cells at 39.5 months (8); small but typical Leydig cells at 43.5 months (9) a few months before onset of meiosis. Ad and Ap spermatogonia are visible.

FIGS. 10, 11. - At the ultrastructural level, Leydig cells had typical, steroidogenic cell features with significantly reduced SER.

A gap junction is visible $(-)$. Fig. $10: \times 30000 ;$ fig. $11: \times 20000$. 
$(\mathrm{P}<0.05)$ more elevated than during meiosis; lipid content was significantly decreased $(P<0.05)$ and mean plasma testosterone level was doubled $(\mathrm{P}<0.001)$ compared to the preceding periods (meiosis and spermiogenesis).

\section{Discussion.}

The postnatal regression of the Leydig cells and their recrudescence around puberty have been described in the Rhesus monkey (Van Wagenen and Simpson, 1965). and in Cercopithecus aethiops (Camatini and Franchi, 1981). The present morphometric study provides data on the development of these cells and on the plasma testosterone profile from birth to puberty.

1) The volume density of Leydig cells remained practically unchanged throughout postnatal development, except in the adult where it decreased. Though the number of Leydig cells per $\mathrm{cm}^{3}$ of testis was significantly less in the adult than in the infant, their absolute number increased approximately fourfold. The size of the Leydig cells decreased significantly during infancy, their absolute cytoplasmic volume being on an average 2.5-fold less than at birth or in adulthood and their SER content 3 to 4 -fold less.

2) The length and intensity of this period of regression seemed to vary according to the animal. However, as reported by Bercu et al. (1983) in Macaca mulatta and Macaca fascicularis, it may be reasonably inferred that maximal Leydig cell regression is reached at about 12 months when the cells are fibroblastlike but still contain typical SER and mitochondria. About 3 to 4 months before onset of meiosis, the size of the Leydig cells increased without changes in the proportion of organelles. During meiosis they had already attained their maximal size and their SER continued to differentiate up to complete spermatogenesis. Thus, it appears that definitive Leydig cell development begins during the last months of infancy. From onset of meiosis on, they return to the differentiation stage at which they were at birth and become adult cells at the end of spermiogenesis, after the SER increases and lipid content decreases.

3) Results obtained on testis differentiation (Fouquet et al., 1983) indicate that Leydig cell number increases almost linearly up to puberty, and even during

PLATE III

Differentiating Leydig cells (L) during meiosis (48 months).

FIGS. 12, 13. - Light microscope views showing evident increase in cell size. $\times 630$.

Fig. 12 : Onset of meiosis in a few sex cords ; fig. 13 : all the cords contain primary spermatocytes (Sp1) and rare round spermatids (Spt). Spermatogonia A and B are visible.

FIGS. 14, 15. - The SER is now well-deve/oped. Elongated mitochondria with longitudinal cristae $(\Rightarrow)$ and gap junctions $(-)$ are seen.

Figs. $14: \times 15000$; fig. $15: \times 14000$. 
(a) $3(5)$

Tindoras

- 10.0 , s.

1. and 1 .

$\rightarrow 14$

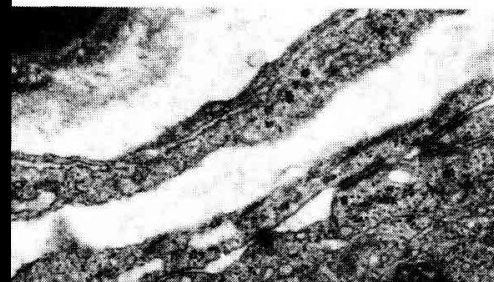

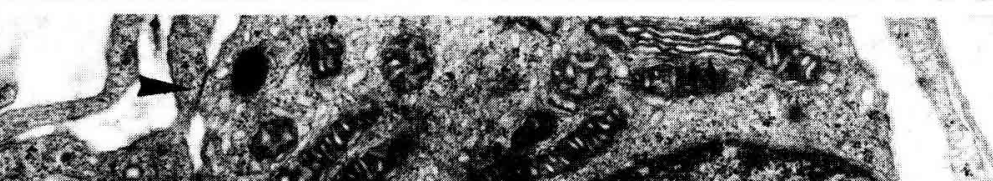

?

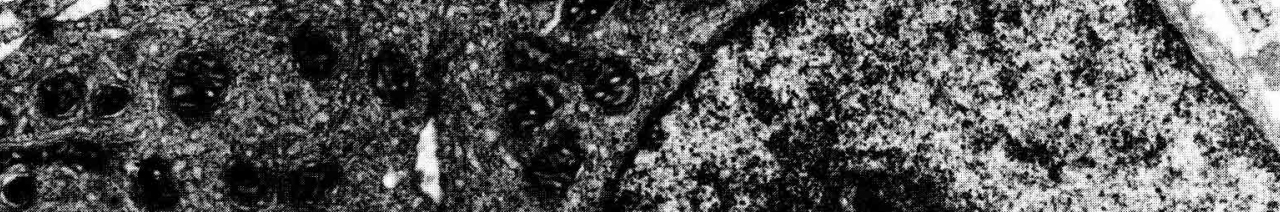

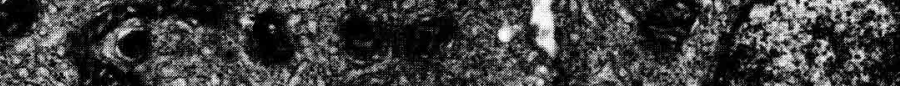

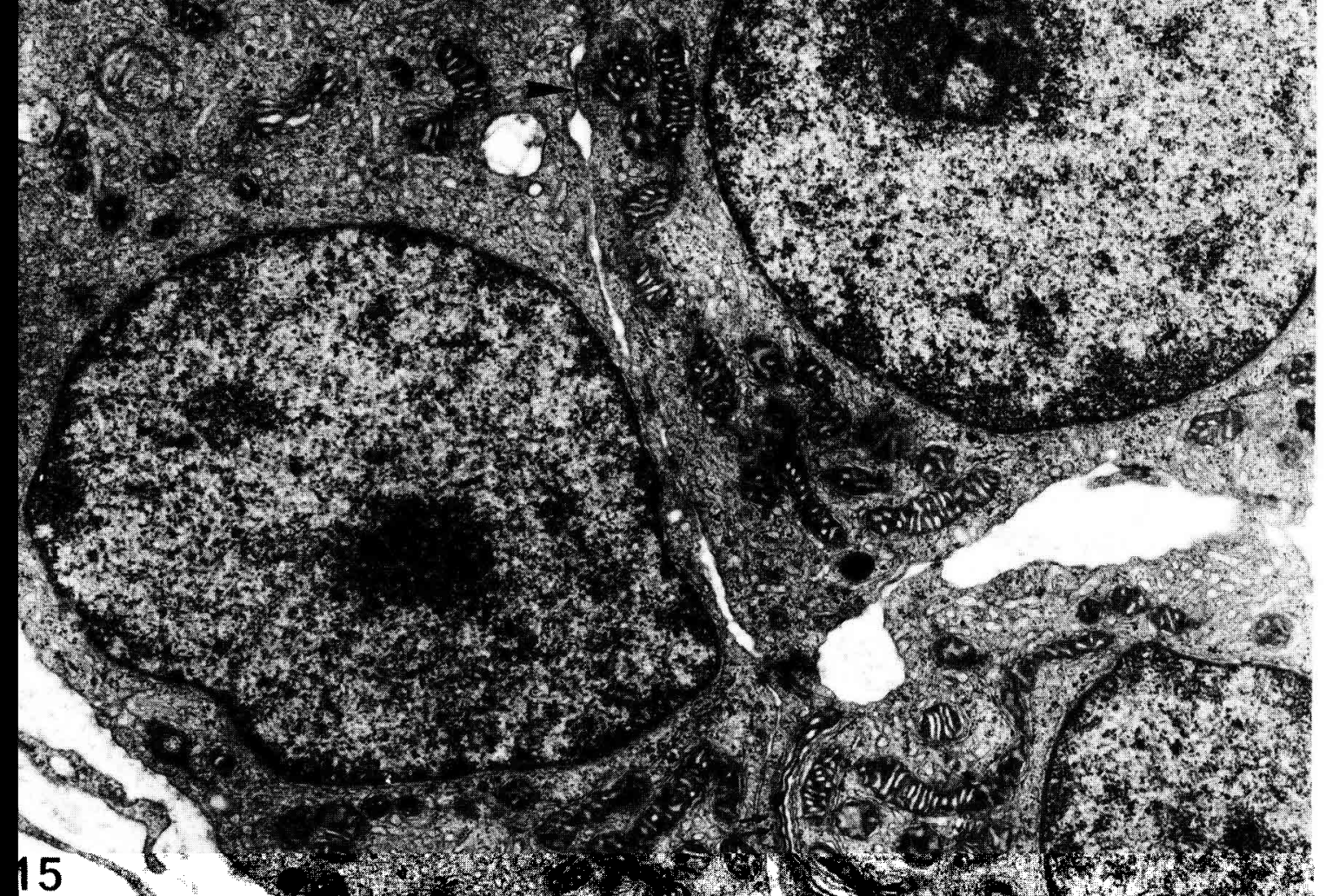


infancy when the cells are less differentiated. Ultrastructural changes were progressive and showed no distinctive character during the various stages of development, suggesting that there are not two different generations of Leydig cells, as proposed in rat (Lording and De Kretser, 1972) or in boar (Van Straaten and Wensing, 1978), but only one generation which develops biphasically.

4) The profile of plasma testosterone from birth to puberty was composed of three periods : a neonatal period with a high testosterone level (about $2 \mathrm{ng} / \mathrm{ml}$ ), infancy with a low level $(<0.5 \mathrm{ng} / \mathrm{ml})$, and a period from onset of meiosis with a dramatic increase of plasma testosterone (mean level : about $3 \mathrm{ng} / \mathrm{ml}$ ) comparable to that measured in the neonatal period but about threefold less than in the adult. Large individual variations occurred during the periods of active testosterone secretion, especially around the onset of meiosis, which might be related to pulsatile activity. A similar profile of plasma testosterone and individual variations in prepuberal Macaca fascicularis were also reported by Steiner and Bremner (1981). An elevated testosterone secretion with wide variations was reported in neonatal Rhesus monkey (Robinson and Bridson, 1978). Surprisingly, only slight differences in plasma testosterone levels were reported between infants and adults in Cercopithecus aethiops (Camatini and Franchi, 1981).

5) In all the species studied, the number (or size) and secretory activity of Leydig cells vary during development (Christensen, 1975 ; Gondos, 1980 ; Allrich et al., 1983), but distinct correlations must still be demonstrated. Our observations in Macaca fascicularis show that individual plasma testosterone levels were significantly and positively correlated with the total volume and total number of Leydig cells : $r=0.63, P<0.01 ; r=0.55, P<0.02$, respectively $(n=20)$. Correlations with whole-cell or cytoplasmic volume were still more significant : $r=0.56, P<0.001(n=30)$. Most of the enzymes involved in testosterone synthesis are sequestered in mitochondria and SER membranes of Leydig cells (Christensen, 1975), but it has been shown that the ability to synthesize testosterone is only correlated with the SER content of adult cells (Zirkin et al., 1980 ; Ewing et al., 1983). Plasma testosterone indirectly reflects the synthesizing ability of Leydig cells but the same pattern of development may be expected concerning plasma testosterone and SER changes. Regression analysis in the present study demonstrates that individual plasma testosterone levels were

PLATE IV

Final Leydig cell (L) development.

FIG. 16. - Spermiogenesis in a 34.5-month old monkey. $\times 630$.

FIG. 17. - Complete spermatogenesis (spermiation) in a 53-month old monkey. $\times 630$.

FIGS. 18, 19. - U/trastructural aspects of adult Leydig cells.

Note membranous whorls (SER) around mitochondria (Mi) almost devoid of cristae (Ci) in association with lipid droplets (Li) (aiso see Plate I, fig. 3). Note packed area of SER and a gap junction $(\rightarrow)$. Fig. $18: \times 60000 ;$ fig. $19: \times 25000$. 
positively correlated with the mean SER volume density of Leydig cells per animal $(r=0.58 ; P<0.001 ; n=32)$ and the mean SER volume of Leydig cells per animal $(r=0.61 ; P<0.001 ; n=32)$, as well as with the total SER volume of the whole testis $(r=0.62 ; P<0.01 ; n=20)$. These results are in agreement with those of Zirkin et al. (1980) who correlated testosterone secretion per gram of Leydig cell with the mean volume or surface density of those cells. A positive correlation was found between testosterone levels and the total volume of mitochondria in the whole testis $(r=0.61 ; P<0.01 ; n=20)$ but not with the volume density of mitochondria. The changes in mitochondrion ultrastructure seemed to be minor but a correlation with the surface density of their membranes cannot be excluded. No correlation was found between plasma testosterone levels and changes in lipids from birth to meiosis but, at later stages, the decrease of lipid volume density was significantly $(P<0.05)$ and negatively $(r=-0.61)$ correlated with plasma testosterone increase. This is in agreement with the current concept that lipid droplets contain substrates for steroid biosynthesis and that their content would decrease when testosterone synthesis is activated (Christensen, 1975).

It is well known that the function and structure of Leydig cells are mainly controlled by LH secretion (reviewed in Levasseur and Thibault, 1980 ; Swerdloff and heber, 1981 ; Ewing et al., 1983). Recent studies in the postnatal monkey have shown that there is a parallel between $\mathrm{LH}$ sensitivity to $\mathrm{GnRH}$ (Monroe et al., 1983) and LH and testosterone secretion (Steiner and Bremner, 1981 ; Bercu et al., 1983) but the Leydig cells were not studied. However, it appears from these results and the present study that the timing of $\mathrm{LH}$ secretion coincides with the different stages of Leydig cell development, and it may be that the changing amplitude of $\mathrm{LH}$ pulses affects Leydig cell differentiation and enhances testosterone secretion at the beginning of puberty. Though these correlations still have to be shown, the present morphometric analysis demonstrates patent correlations between Leydig cell development (including cell size, number and SER content) and the plasma testosterone profile during postnatal development. From an ultrastructural point of view, only one generation of Leydig cells with biphasic development has been observed, but this does not preclude the possible presence of functionally different populations of Leydig cells as demonstrated in rat (Chase and Payne, 1983). It appears that onset of meiosis and the few months preceding it are a critical period for both the definitive development of Leydig cells and the pubertal rise of plasma testosterone. Similar results were reported in other species (Gondos, 1980) but it is not clear whether testosterone rise plays a decisive role or not in the onset of meiosis or in its preparation.

Reçu en septembre 1983.

Accepté en décembre 1983.

Acknowledgements. - The authors wish to thank Professor C. Thibault for encouragement and discussion. Special thanks are due P.-C. Léglise (deceased in October 1983) for surgery, the technicians of our monkey houses for careful maintenance of the experimental animals and Mr. Gouzy for the photography. This work was supported by the "Délégation Générale de la Recherche Scientifique et Technique " (contracts 79-7.1288 and 80-7.0357). 
Résumé. Relations entre la morphométrie des cellules de Leydig et la testostérone plasmatique au cours du développement postnatal du singe Macaca fascicularis.

Pendant la période néo-natale 10 à $3 / 4$ mois), le testicule contient en moyenne $4,6 \times 10^{6}$ cellules de Leydig représentant $4,2 \%$ de son volume, leur cytoplasme contient $10,2 \%$ de SER. Pendant l'enfance (après $3 / 4$ mois jusqu'à 45 mois), les cellules de Leydig sont atrophiées mais leur nombre augmente de sorte que leur densité de volume ne change pas. Leur volume cytoplasmique $\left(454 \mu \mathrm{m}^{3}\right)$ qui est environ 2,5 fois plus petit qu'à la naissance $\left(1119 \mu \mathrm{m}^{3}\right)$ ou à la puberté $\left(1170 \mu \mathrm{m}^{3}\right)$, contient seulement $8,7 \%$ de SER. Lors de l'initiation de la méiose (38 à 52 mois), le nombre et la densité de volume des cellules de Leydig ne sont pas modifiés, mais elles atteignent leur taille maximale et une proportion de SER comparables à celles mesurées à la naissance. Quand la spermatogenèse est complète, le nombre de cellules de Leydig et leur contenu en SER sont significativement augmentés, mais elles ne représentent plus que $0,8 \%$ du volume testiculaire. A l'exception d'une réduction significative lorsque la spermatogenèse est complète, la quantité de lipides des cellules de Leydig ne change pas au cours du développement et la densité de volume des mitochondries ne varie pas.

Le niveau moyen de la testostérone plasmatique est $2 \mathrm{ng} / \mathrm{ml}$ chez les nouveaux-nés ; $0,4 \mathrm{ng} / \mathrm{ml}$ chez les enfants, il monte à $3 \mathrm{ng} / \mathrm{ml}$ pendant l'initiation de la méiose et atteint $10 \mathrm{ng} / \mathrm{ml}$ chez les adultes. Le profil évolutif de la testostérone est corrélé positivement et significativement avec le volume total et le nombre total des cellules de Leydig $(P<0,01$ et $P<0,02$, respectivement), une corrélation plus forte est observée avec les changements de volume cytoplasmique $(P<0,001)$. En outre, les niveaux de la testostérone plasmatique sont corrélés positivement et significativement avec l'évolution du SER des cellules de Leydig : densité de volume et volume moyen par cellule ( $P<0,001)$, volume total du SER par testicule $(P<0,01)$.

\section{References}

ALLRICH R. D., CHRISTENSON R. K., FORD J. J., ZIMMERMAN D. R., 1983. Pubertal development of the boar : age-related changes in testicular morphology and in vitro production of testosterone and estradiol-17 $\beta$. Biol. Reprod., 28, 902-909.

BERCU B. B., LEE B. C., PINEDA J. L., SPIל,IOTIS B. E., DENMAN D. W., HOFFMAN H. J., BROWN T. J., SACHS H. C., 1983. Male sexual development in the monkey. I. Crosssectional analysis of pulsatile hypothalamic-pituitary testicular function. J. clin. Endocrinol. Metab., 56, 1214-1226.

BOLENDER R. P., 1978. Correlation of morphometry and stereology with biochemical analysis of cell fractions. Int. Rev. Cytol., 55, 247-289.

CAMATINI M., FRANCHI E., 1981. Postnatal differentiation of Leydig cells in the African green monkey. Am. J. Primatol., 1, 231-239.

CAMATINI M., FRANCHI E., DE CURTIS I., 1981. Ultrastructure of Leydig cells in the African monkey. J. Uitrastr. Res., 76, 224-234.

CHASE D. J., PAYNE A., 1983. Changes in distribution and androgen production of Leydig cells of two populations during sexual maturation in the rat. Endocrinology, 112, 29-34.

CHRISTENSEN A. K., 1975. Leydig cells. In GREEP R. O., ASTWOOD E. B., Handbook of physiology. Amer. physiol. Soc., Washington, vol. 5, Sect. 7, 57-94.

DANG D. C., 1977. Resumption of menstruation and fertility after cesarian in Macaca fascicularis. Ann. Biol. anim. Bioch. Biophys., 17, 325-329.

DANG D. C., MEUSY-DESSOLLE N., 1979. Testosterone levels in umbilical cord blood, maternal peripheral plasma and amniotic fluid of the crab-eating monkey (Macaca fascicularis). Ann. Biol. anim. Bioch. Biophys., 19, 1307-1316.

EWING L. L., WING T.-Y., COCHRAN R. C., KROMANN N., ZIRKIN B. R., 1983 . Effect of luteinizing hormone on Leydig cell structure and testosterone secretion. Endocrinology, 112, 1763-1769.

FAIMAN C., WINTER J. S. D., REYES F. 1., 1981. Endocrinology of the fetal testis, 81-105. In BURGER H., De KRETSER D., The testis, Raven Press, New York.

Reproduction Nutrition Développement $n^{\circ} 3-84$. -8 . 
FOUQUET J.-P., 1982. Evolution ultrastructurale des cellules germinales foetales jusqu'aux spermatogonies adultes chez le Singe Macaca fascicularis. Reprod. Nutr. Dévelop., 22, 767783.

FOUQUET J.-P., MEUSY-DESSOLLE N., DANG D. C., 1983. Morphometry of fetal Leydig cells in the monkey (Macaca fascicularis); correlation with plasma testosterone. Biol. Cell., 49 (in press).

GONDOS B., 1980. Development and differentiation of the testis and male reproductive tract, 3-20. In STEINBERGER A., STEINBERGER E., Testicular development, structure and function, Raven Press, New York.

GONDOS B., RENSTON R. H., GOLDSTEIN D. A., 1976. Postnatal differentiation of Leydig cells in the rabbit testis. Amer. J. Anat., 145, 167-182.

GONDOS B., MORRISON K. P., RENSTON R. H., 1977. Leydig cell differentiation in the prepubertal rabbit testis. Biol. Reprod., 17, 745-748.

LEVASSEUR M. C., THIBAULT C., 1980. De la puberté à la sénescence. INRA. Actualités scientifiques et agronomiques. Masson éd., Paris, $120 \mathrm{p}$.

LORDING D. W., De KRETSER D. M., 1972. Comparative ultrastructural and histochemical studies of the interstitial cells of the rat testis during fetal and postnatal development. J. Reprod. Fertil., 29, 261-269.

MEUSY-DESSOLLE N., 1975. Variations quantitatives de la testosterone plasmatique chez le porc mâle, de la naissance à l'âge adulte. C. R. Acad. Sci. (D), Paris, 281, 1875-1878.

MONROE S. E., YAMAMOTO M., JAFFE R. B., 1983. Changes in gonadotrope responsivity to gonadotropin-releasing hormone during development of the Rhesus monkey. Biol. Reprod., 29, 422-431.

MORI H., CHRISTENSEN A. K., 1980. Morphometric analysis of Leydig cells in the normal rat testis. J. Cell Biol., 84, 340-354.

MORI H., SHIMIZU D., TAKEDA A., TAKIOKA Y., FUKUNISHI R., 1980. Stereological analysis of Leydig cells in normal guinea-pig testis. J. Electron Microsc., 29, 8-21.

MORI H., SHIMIZU D., FUKUNISHI R., CHRISTENSEN A. K., 1982a. Morphometric analysis of testicular Leydig cells in normal adult mice. Anat. Rec., 204, 333-339.

MORI H., HIROMOTO N., NAKAHARA M., SHIRAISHI T., 1982b. Stereological analysis of Leydig cell ultrastructure in aged humans. J. clin. Endocrinol. Metab., 55, 634-641.

PEYRAT J.-Ph., MEUSY-DESSOLLE N., GARNIER J., 1981. Changes in Leydig cells and luteinizing hormone receptors in porcine testis during postnatal development. Endocrinology, 108, 625-631.

ROBINSON J. A., BRIDSON W. E., 1978. Neonatal hormone patterns in the macaque. I. Steroids. Biol. Reprod., 19, 773-778.

STEINER R. A., BREMNER W. J., 1981. Endocrine correlates of sexual development in the male monkey, Macaca fascicularis. Endocrinology, 109, 914-919.

SWERDLOFF R. S., HEBER D., 1981. Endocrine control of testicular function from birth to puberty, 107-126. In BURGER H., De KRETSER D., The testis, Raven Press, New York.

Van STRAATEN H. W. M., WENSING C. J. G., 1978. Leydig cell development in the testis of the pig. Biol. Reprod., 18, 86-93.

Van WAGENEN G., SIMPSON M. E., 1965. Embryology of the ovary and testis in Homo sapiens and Macaca mulatta. Yale Univ. Press, New-Haven and London.

WEIBEL E. R., KISTLER G. S., SCHERLE W. F., 1966. Practical stereological methods for morphometric cytology. J. Cell Biol., 30, 23-38.

ZIRKIN B. R., EWING L. L., KROMANN N., COCHRAN R. C., 1980. Testosterone secretion by rat, rabbit, guinea-pig, dog and hamster testis perfused in vitro : correlation with Leydig cell ultrastructure. Endocrinology, 107, 1867-1874. 